\title{
About the in vivo discriminatory capacity of photoplethysmography versus laser Doppler flowmetry
}

\author{
Acerca da capacidade discriminatória in vivo da fotopletismografia versus fluxometria por \\ laser Doppler
}

\author{
Clemente Rocha $^{1 *}$, Henrique Silva ${ }^{1,2}$, Hugo Ferreira ${ }^{3}$ and L. Monteiro Rodrigues ${ }^{1,2}$ \\ ${ }^{1}$ CBIOS - Universidade Lusófona's Research Center for Biosciences and Health Technologies (UDE), Campo Grande, 376 , \\ 1749-024, Lisboa, Portugal \\ ${ }^{2}$ Universidade de Lisboa, Faculty of Pharmacy, Pharmacol. Sc Depart - Lisboa, Portugal \\ ${ }^{3}$ Universidade de Lisboa, Faculty of Sciences - Institute of Biophysics and Biomedical Engineering \\ e-mail: c.rocha.dr@gmail.com
}

\begin{abstract}
Peripheral vascular disease (PVD) comprises many pathological entities, and a variety of clinical expressions, being the $3 \mathrm{rd}$ most reported cause of cardiovascular disease. PVD continues to motivate more and better research to understand the many complexities involved, and to develop more effective preventive measures and therapeutics. Photoplethysmography (PPG) is a classic non-invasive technique used to explore in vivo circulation, progressively replaced by laser Doppler flowmetry (LDF). Recent advances enable the development of a new PPG system that seems to clearly improve the applicability of this technique. In this study, we apply and compare these two noninvasive measurement techniques after a massage manoeuvre in the human leg. This exploratory study involved seven volunteers, both sexes $(19.6 \pm 1.3$ years old). Flow measurements took place in both limbs before (I), during (II) and after the massage manoeuvre (III). Other variables, including pulse and respiratory rates and blood pressure (BP), were also quantified. Results show that the simultaneous use of LDF and PPG enables the detection of discrete changes in blood flow that could not be detected with a single technique. Furthermore, it also shows that, under these conditions, the massage improves the lower limb perfusion in both limbs (test and control).
\end{abstract}

Keywords: Microcirculation; LDF; PPG; massage; vascular regulation

\begin{abstract}
Resumo
A doença vascular periférica (DVP) compreende muitas entidades patológicas e uma variedade de expressões clínicas, sendo a terceira causa principal da doença cardiovascular. A DVP ainda continua a motivar mais e melhor investigação para compreender as muitas complexidades envolvidas, e desenvolver medidas preventivas e terapêuticas mais eficazes. A fotopletismografia (FPG) é uma técnica clássica não invasiva utilizada para explorar a circulação in vivo, que tem vindo a ser progressivamente substituída pela fluxometria por laser Doppler (FLD). Avanços recentes permitiram o desenvolvimento de um novo sistema FPG que parece melhorar claramente a aplicabilidade desta técnica. Neste estudo, aplicamos e comparamos estas duas técnicas de medição não-invasiva após uma manobra de massagem no membro inferior humano. Este estudo exploratório envolveu sete voluntários de ambos sexos (19,6 $\pm 1,3$ anos). As medições de fluxo foram feitas em ambos os membros antes da manobra (I), durante a massagem (II) e após a recuperação (III). Outras variáveis, incluindo as frequências de pulso e respiratória, e pressão arterial (PA) também foram quantificadas. Os resultados mostram que o uso simultâneo de FLD e FPG permite detetar alterações discretas no fluxo sanguíneo que não poderíamos detetar com apenas uma das técnicas. Além disso, também mostram que, nestas condições, a massagem melhora a perfusão do membro inferior em ambos os membros (teste e controlo).
\end{abstract}

Palavras-chave: Microcirculação; FLD; FPG; massagem; regulação vascular 


\section{Introduction}

Peripheral vascular disease (PVD) comprises many pathological entities and involves a variety of clinical expressions, from heavy legs syndrome to muscular and osteoarticular inflammatory involvement and ulcers ${ }^{[1,2]}$. It is considered a significant public health problem, and one which may lead to poor quality of life ${ }^{[2]}$. In Portugal, the PVD prevalence is estimated to reach $5.9 \%$ of the population, mostly affecting the elderly ${ }^{[3]}$. Its significant expression as the $3^{\text {rd }}$ most reported cause of cardiovascular disease continues to motivate more and better research on the subject in order to understand the involved complexities and develop more effective preventive measures and therapeutics.

The skin is known to be an adequate location to address a wide range of functional aspects of microcirculation $^{[4,5]}$ and, for that reason, laser doppler flowmetry (LDF) and photoplethysmography (PPG) became well-known, non-invasive techniques to quantify flow variables in conditions as closely as possible from the normal physiological state ${ }^{[4,6-9]}$.

LDF has gained great popularity in the last decades as a non-invasive assessment tool in vascular research and medicine. It has been explored as a useful tool in basic research to study microcirculatory regulation mechanisms in both physiological and pathophysiological states including diabetes mellitus ${ }^{[10]}$, PVD ${ }^{[1]}$, kidney disease ${ }^{[12]}$, and coronary artery disease ${ }^{[13]}$, among others, although its usefulness as a diagnostic tool is largely limited to its low reproducibility. PPG is a much older technology commonly included in many current medical devices such as pulse oximeters, and digital beat-to-beat blood pressure systems ${ }^{[8]}$. Although based in similar optical principles, LDF and PPG are technically very different, and also differ in terms of cost. Recent technological advances promoted a clear evolution of the classic PPG, drawing our attention to this new generation hardware and software that have evolved in terms of portability and data acquisition, showing a quantitative potential until now only expected for LDF signals ${ }^{[14]}$.

In this study we explore the impact of a discrete intervention on the local microcirculation status of the lower limb, using a massage protocol as instrument, in order to evaluate the discriminatory capacity of this new generation of PPG in the detection and quantification of peripheral vascular circulation and to compare it to the information derived by LDF.

\section{Introdução}

A doença vascular periférica (DVP) compreende muitas entidades patológicas e uma enorme variedade de expressões clínicas, desde a síndrome da "pernas pesadas" até ao envolvimento inflamatório muscular e osteoarticular, e à úlcera ${ }^{[1,2]}$. É considerado um problema de saúde pública, com grave impacto sobre a qualidade de vida ${ }^{[2]}$. Em Portugal, estima-se que a prevalência da DVP chegue a 5,9\% da população, afetando principalmente os idosos ${ }^{[3]}$. Constituindo a $3^{\text {a }}$ causa mais importante de doença cardiovascular, continua a motivar mais e melhor investigação, a fim de compreender as complexidades envolvidas e desenvolver medidas preventivas e terapêuticas mais eficazes.

A pele é reconhecida como um orgão adequado à abordagem de vários aspetos funcionais da microcirculação $[4,5]$, e por essa razão, a fluxometria por laser Doppler (FLD) e a fotopletismografia (FPG) tornaram-se técnicas não invasivas, bem conhecidas, para quantificar através da pele, variáveis de fluxo em condições tão próximas quanto possível do estado fisiológico normal [4,6,9]. A FLD ganhou grande popularidade nas últimas décadas como uma ferramenta de avaliação em medicina vascular, e utilizada em investigação básica para estudar os mecanismos de regulação microcirculatória em diversos contextos incluindo a diabetes mellitus ${ }^{[10]}$, a DVP ${ }^{[11]}$, a doença renal ${ }^{[12]}$, a doença arterial coronária ${ }^{[13]}$, entre outras, embora a sua utilidade em diagnóstico esteja limitada à sua baixa reprodutibilidade. A FPG é uma tecnologia bastante mais antiga, aproveitada em muitos dispositivos médicos atuais, como oxímetros de pulso e sistemas de pressão arterial digitais "beat to beat" ${ }^{[8]}$. Embora baseados em princípios óticos similares, a FLD e FPG são tecnicamente muito diferentes e, igualmente diferentes em termos de custo. Avanços tecnológicos recentes permitiram uma clara evolução da FPG clássica, chamando a nossa atenção para esta nova geração de hardware e software que evoluiu em termos de portabilidade e aquisição de dados, mostrando um potencial quantitativo até agora reservado apenas aos sinais de FLD.

Neste estudo, analisamos o impacto de uma intervenção discreta sobre o estado da microcirculação local do membro inferior, um protocolo de massagem, para avaliar a capacidade discriminatória desta nova geração de FPG na deteção e quantificação da circulação vascular periférica, comparativamente à FLD. 


\section{Materials and Methods}

A group of seven young healthy volunteers of both sexes ( 3 females, 4 males), aged between 18 and 22 years old $(19.6 \pm 1.3)$ and selected from previously outlined inclusion and non-inclusion criteria ${ }^{[5]}$, participated in the study after informed written consent. All procedures were developed in accordance with the Helsinki Declaration and subsequent amendments ${ }^{[15]}$. Volunteers were asked to refrain from consuming caffeinated and alcoholic beverages 24 hours prior to experiments. All procedures were carried out in a room with controlled temperature $\left(21 \pm 1^{\circ} \mathrm{C}\right)$ and humidity (40-60\%) conditions. Volunteers acclimatized for 20 minutes in the supine position prior to measurements. The experimental protocol consisted of a 5 minute massage session applied from the foot to the knee on one randomly selected limb. The volunteers remained lying supine (Figure 1) during three recording phases: 10 minutes resting (phase I), 5 minute upward leg and foot massage for 5 minutes (phase II), and 10 minute recovery (phase III).

\section{Materiais e Métodos}

Um grupo de sete voluntários jovens, saudáveis, de ambos os sexos ( 3 do sexo feminino, 4 do sexo masculino) com idades entre os 18 e os 22 anos $(19,6 \pm$ $1,3)$, selecionados a partir de critérios de inclusão e não inclusão previamente delineados ${ }^{[5]}$, participaram do estudo após darem o seu consentimento informado por escrito. Todos os procedimentos foram desenvolvidos em conformidade com a Declaração de Helsínquia e respectivas emendas posteriores ${ }^{[15]}$. Os voluntários foram instruídos para não consumir bebidas cafeinadas nem alcoólicas $24 \mathrm{~h}$ antes das experiências. Todos os procedimentos foram realizados em ambiente com temperatura $\left(21 \pm 1^{\circ} \mathrm{C}\right)$ e humidade $(40-60 \%)$ controladas. Os voluntários mantiveram-se em repouso durante 20 minutos em supinação antes das medições.

O protocolo experimental consistiu em uma sessão de massagem de 5 min aplicada do pé ao joelho para um membro aleatoriamente selecionado, mantendo os voluntários em supinação (Figura 1), envolvendo 3 fases de registo - $10 \mathrm{~min}$ em repouso (fase I), 5 min de massagem da perna e pé em sentido ascendente durante 5 minutos (fase II), recuperação de 10 min (fase III).

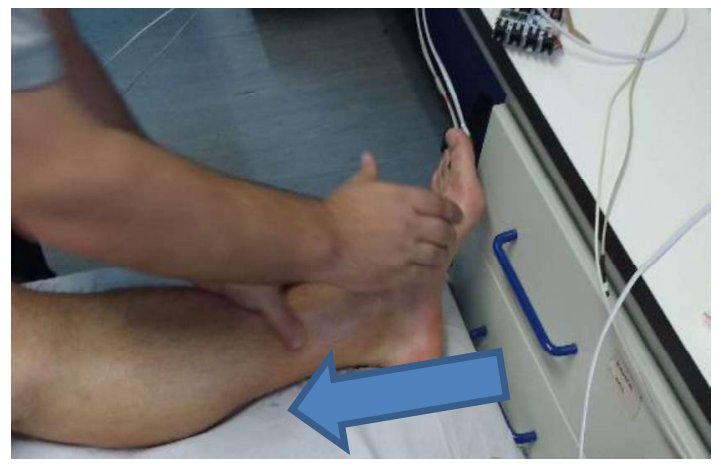

Figure 1/ Figura 1 - Massage application protocol (direction indicated by the arrow)

Aplicação do protocolo de massagem (direção indicada pela seta) 

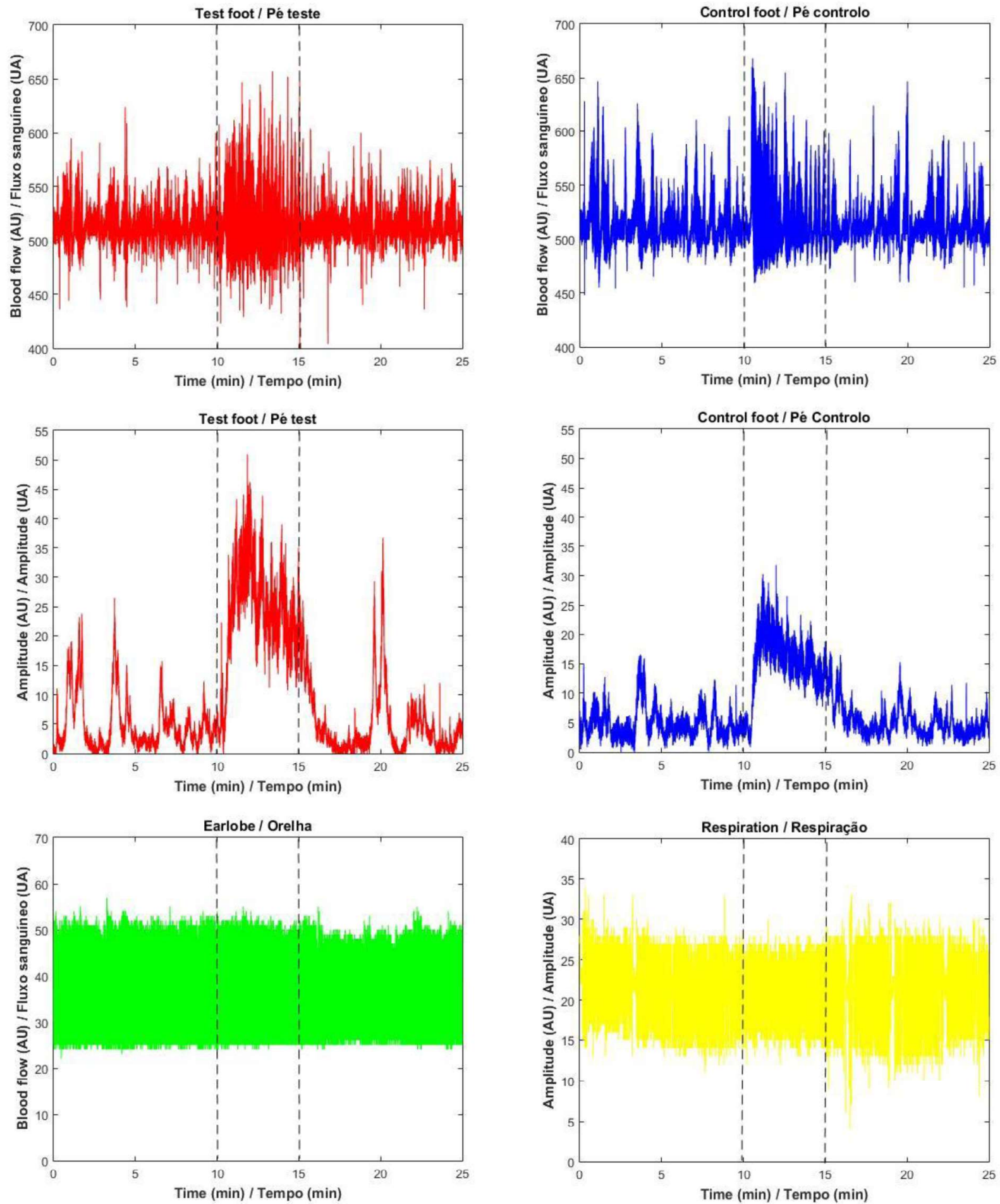

Figure 2/ Figura 2 - Recordings for a representative volunteer (female, 19 years old) of the PPG (upper left for test foot; upper right for control foot), LDF (middle left for test foot; middle right for control foot; lower left for earlobe) and respiration (lower right) during the $25 \mathrm{~min}$ protocol. Vertical lines indicate phase transitions. Sinais de FPG (em cima à esquerda para pé teste; em cima à direita para pé controlo), FLD (no centro à esquerda para pé teste; no centro à direita para pé controlo; em baixo à esquerda para orelha), e respiração (em baixo à direita) de um voluntário representativo (feminino, 19 anos de idade) durante o protocolo de 25 minutos. As linhas verticais indicam as transições de fase. 
Variables included local blood flow, measured by LDF (457 thermostatic small angled probe, PF5010 system, Perimed, Sweden), and by PPG (BVP sensor, Plux Biosignals, Portugal), both expressed in arbitrary units (AU). Skin temperature was also registered (457 thermostatic small angled probe, PF5010 system, Perimed, Sweden). LDF signals were acquired at a $32 \mathrm{~Hz}$ sampling rate. Sensors were applied in the most distal areas - for PPG on the plantar surface of the first toe, in both feet $\left(\mathrm{PPG}_{\mathrm{T}}\right.$ for the test foot; $\mathrm{PPG}_{\mathrm{C}}$ for the control foot), and on one randomly chosen earlobe $\left(\mathrm{PPG}_{\mathrm{E}}\right)$, and for LDF on the plantar surface of the second toe in both feet $\left(\mathrm{LDF}_{\mathrm{T}}\right.$ for the test foot; $\mathrm{LDF}_{\mathrm{C}}$ for the control foot). The pulse rate (PR) was calculated from the ear lobe PPG signal. Respiratory rate (RR) was measured with a pneumography sensor (PZT sensor, Plux Biosignals, Portugal), placed around the thorax on the projection of the sternoxiphoid joint. The PPG and PZT sensors were connected to a BITalino Plugged board (Plux Biosignals, Portugal) and signals were acquired at a $100 \mathrm{~Hz}$ sampling rate. The systolic (SBP) and diastolic blood pressure (DBP) were also measured in the arm by a digital device (Tensoval comfort, Hartman, Germany) on minutes 3, 5, 7 (phase I), 13, 14, 15 (phase II) and 18,20 and 22 (phase III) of the protocol, and the mean values for each phase were calculated. Both feet and sensors were kept in the same position during the experiments.

Descriptive and non-parametric statistics were applied to data (SPSS 21.0, USA). Phase comparisons were carried out with the Wilcoxon test for paired samples for each leg, while the Mann-Whitney U test for independent samples was used for leg comparisons. The correlation between LDF and PPG signals was assessed with the Spearman test. A significance level of $95 \%$ was adopted for all statistic tests.

\section{Results and Discussion}

Table 1 resumes the mean values of the measured variables for all phases of the protocol. No significant differences between both feet perfusion were found with either LDF or PPG, suggesting a homogeneous blood distribution along the lower limbs. During massage application, statistically significant perfusion increases in both feet were detected $\left(\mathrm{p}=0.018\right.$ for $\mathrm{LDF}_{\mathrm{T}}$ and $\mathrm{LDF}_{\mathrm{C}}$, $\mathrm{p}=0.028$ for $\mathrm{PPG}_{\mathrm{T}}$ and $\mathrm{PPG}_{\mathrm{C}}$ ), despite the fact that the response in the test foot was more pronounced in com-
As variáveis registadas foram o fluxo sanguíneo local, medido por FLD (sonda termostática 457 de ângulo curto, sistema PF5010, Perimed, Suécia), e por FPG (sensor BVP, Plux Biosignais, Portugal), ambos expressos em unidades arbitrárias (UA). A temperatura da pele foi também registada (sonda termostática 457 de ângulo curto, sistema PF5010, Perimed, Suécia). Os sinais de FLD foram adquiridos a uma frequência de amostragem de $32 \mathrm{~Hz}$. Os sensores foram aplicados nas áreas mais distais - a FPG na superfície plantar do primeiro dedo do pé, em ambos os pés $\left(\mathrm{FPG}_{\mathrm{T}}\right.$ para o pé de teste, $\mathrm{FPG}_{\mathrm{C}}$ para o pé de controlo) e num lóbulo da orelha escolhido aleatoriamente $\left(\mathrm{FPG}_{\mathrm{o}}\right)$, na superfície plantar do segundo dedo do pé, em ambos os pés $\left(\mathrm{FLD}_{\mathrm{T}}\right.$ para o pé de teste, $\mathrm{FLD}_{\mathrm{C}}$ para o pé de controlo). A frequência de pulso (FP) foi calculada a partir do sinal de FPG do lóbulo da orelha. A frequência respiratória (FR) foi medida com um sensor de pneumografia (sensor PZT, Plux Biosignals, Portugal), colocado em torno do tórax, na projeção da sínfise xifoesternal. Os sensores FPG e PZT foram ligados a uma placa BITalino Plugged (Plux Biosignals, Portugal) e os sinais adquiridos a uma frequência de amostragem de $100 \mathrm{~Hz}$. As pressões arteriais sistólica (PAS) e diastólica (PAD) foram também medidas no braço, por um dispositivo digital (Tensoval comfort, Hartman, Alemanha) nos minutos 3, 5, 7 (fase I) 13, 14, 15 (fase II) e 18, 20 e 22 (Fase III) do protocolo, calculando os valores médios para cada fase. Ambos os pés e sensores foram mantidos na mesma posição durante as experiências.

Foram aplicadas ferramentas de análise estatística descritiva e não-paramétrica aos dados (SPSS 21.0, EUA). As comparações de fases foram realizadas com o teste de Wilcoxon para amostras emparelhadas, em cada perna, enquanto o teste U de Mann-Whitney para amostras independentes foi utilizado para comparações entre os membros. A correlação entre os sinais de FLD e FPG foi avaliada pelo teste de Spearman. Foi adotado um nível de significância de $95 \%$ para todos os testes estatísticos.

\section{Resultados e Discussão}

A Tabela 1 resume os valores médios das variáveis medidas em todas as fases do protocolo. Não foram encontradas diferenças significativas entre as perfusões de ambos dos pés com FLD ou FPG, sugerindo uma distribuição homogénea do sangue ao longo dos membros inferiores. Durante a aplicação da massagem, foram detetados aumentos estatisticamente significativos da perfusão em ambos os pés ( $\mathrm{p}=0,018$ para $\mathrm{FLD}_{\mathrm{T}} \mathrm{e}$ $\mathrm{FLD}_{\mathrm{C}}, \mathrm{p}=0,028$ para $\mathrm{FPG}_{\mathrm{T}}$ e $\mathrm{FPG}_{\mathrm{C}}$ ), apesar de a res- 
parison to the control (LDF: $119.4 \%$ vs $51.5 \%$; PPG: $53.4 \%$ vs $23.6 \%$ ). While the test foot response seems to be due to a direct mechanical mobilization of the blood, promoted by the massage, the increase registered in the control foot suggests that this mobilization also affects the other leg, likely due to a regional regulation intended to maintain the lower limb (regarded as one unit) circulatory homeostasis.

PPG quantifies the amount of visible light reflected by microcirculatory vessels, in proportion to the blood volume perfusing the vessels. Its typical 'wave' form is explained by the variation of blood volume that occurs after a given heartbeat ${ }^{[8]}$. In contrast, LDF quantifies the velocity of circulating red blood cells (RBC), which is proportional to the frequency shift suffered by an impinging laser beam, that is, the 'Doppler effect' ${ }^{[16]}$. After multiplying this velocity by an estimated stochastic value of RBC concentration, a 'flow' value is reached. The different percent changes detected in both feet with both LDF and PPG between phases are likely attributable to the different depths of reading from the two sensors ${ }^{[17,18]}$, and this difference should be further investigated. Despite these technical differences, signals from both techniques were similar in both feet, as shown by a positive significant correlation here found $(\mathrm{N}=42 ; \rho=0.673 ; \mathrm{p}<0.001)$.

SBP, DBP and PR decreased significantly during massage application ( $\mathrm{p}=0,018$ for all variables), and returned to baseline values in the recovery phase (Table 1). The reduction of these haemodynamical markers during the massage has been described previously, and might be related to a related increase in parasympathetic activity ${ }^{[19]}$. RR increased significantly during the massage $(p=0,018)$, which might be explained by the associated relaxing effect described by volunteers, eventually affecting central and peripheral neural activity ${ }^{[20,21]}$.

Some studies have reported an increase in skin temperature during the application of a massage ${ }^{[22,23]}$, however, in our study conditions, the temperature did not change significantly throughout the protocol. posta no pé teste ter sido mais pronunciada em relação ao controlo (FLD: $119,4 \%$ vs 51,5\%, FPG: 53,4\% vs $23,6 \%$ ). Enquanto a resposta do pé teste parece ser devida a uma mobilização mecânica direta de sangue, promovida pela massagem, o aumento registado no pé de controlo sugere que essa mobilização também afeta a outra perna, provavelmente devido a uma regulação regional destinada a manter a homeostasia circulatória no membro inferior (considerado como uma unidade).

A FPG quantifica a luz visível refletida pelos vasos microcirculatórios, em proporção ao volume de sangue perfundido. A forma típica de 'onda' é explicada pela variação do volume de sangue que ocorre após um determinado batimento cardíaco ${ }^{[8]}$. Quanto à FLD, esta quantifica a velocidade dos glóbulos vermelhos $(\mathrm{GV})$ circulantes, que é proporcional ao desvio de frequência sofrido pela incidência de um feixe de luz laser, isto é, o "efeito Doppler" ${ }^{[16]}$. Depois de multiplicar esta velocidade por um valor estocástico estimado da concentração de GV, é obtido um valor de "fluxo". As diferentes percentagens de alterações detetadas em ambos os pés com FLD e FPG entre as fases são provavelmente atribuíveis às diferentes profundidades de leitura dos dois sensores ${ }^{[17,18]}$, que devem ser investigados. Apesar dessas diferenças técnicas, os sinais de ambas as técnicas foram semelhantes em ambos os pés, como mostrado por uma correlação significativa positiva encontrada aqui ( $\mathrm{N}=42 ; \mathrm{p}=0,673 ; \mathrm{p}<0,001)$.

A PAS, PAD e FP diminuíram significativamente durante a aplicação da massagem ( $p=0,018$ para todas as variáveis) e retornaram aos valores basais na fase de recuperação (Tabela 1). A redução destes marcadores hemodinâmicos durante a massagem tem sido descrita e pode estar relacionada com um aumento relacionado na atividade parassimpática ${ }^{[19]}$. A FR aumentou significativamente durante a massagem $(p=0,018)$, o que pode ser explicado pelo efeito relaxante associado descrito pelos voluntários, eventualmente afetando as atividades nervosa central e periférica ${ }^{[20,21]}$.

Alguns estudos relataram um aumento da temperatura da pele com a massagem ${ }^{[22,23]}$, no entanto, não encontrámos este dado, uma vez que a temperatura não se alterou significativamente ao longo do protocolo. 
Table 1/ Tabela 1 - Mean, standard deviation and percent change of the variables measured. Statistical comparison of the mean values of phases II and III regarding phase I is presented ( $<<0.05 ; *$ - statistically significant) Média, desvio-padrão e variação percentual das variáveis medidas. É apresentada a comparação estatística dos valores médios das fases II e III com a fase I ( $p<0.05 ; *$ - estatisticamente significativo)

\begin{tabular}{|c|c|c|c|c|c|c|}
\hline Variable / Variável & & Phase I / Fase I & Phase II / Fase II & Phase III / Fase III & $\Delta \mathrm{II}-\mathrm{I}(\%)$ & $\begin{array}{c}\Delta \mathrm{IIII}-\mathrm{I} \\
(\%)\end{array}$ \\
\hline \multirow{2}{*}{$\mathbf{L D F}_{\mathrm{T}}(\mathbf{A U}) / \mathbf{F L D}_{\mathrm{T}}(\mathbf{U A})$} & Mean & 8.0 & 17.6 & 9.3 & 119.4 & 14.0 \\
\hline & sd & 3.8 & 5.0 & 5.6 & $\mathrm{p}=0.018^{*}$ & $\mathrm{p}=0.499$ \\
\hline \multirow{2}{*}{$\mathbf{L D F}_{\mathrm{C}}(\mathbf{A U}) / \mathrm{FLD}_{\mathrm{C}}(\mathrm{UA})$} & Mean & 7.6 & 11.5 & 8.3 & 51.5 & 10.1 \\
\hline & sd & 4.2 & 4.8 & 5.5 & $\mathrm{p}=0.018^{*}$ & $\mathrm{p}=1.00$ \\
\hline $\mathbf{L D F}_{\mathrm{T}}$ vs $\mathbf{L D F}_{\mathrm{C}}$ & & $\mathrm{p}=0.902$ & $\mathrm{p}=0.053$ & $\mathrm{p}=0.902$ & - & - \\
\hline \multirow{2}{*}{ Skin temperature $\left({ }^{\circ} \mathrm{C}\right)$} & Mean & 23.6 & 23.5 & 23.4 & -0.54 & -0.71 \\
\hline & sd & 1.9 & 1.7 & 1.7 & -12.7 & -10.25 \\
\hline \multirow{2}{*}{$\mathbf{P P G}_{\mathrm{T}}(\mathrm{AU}) / \mathrm{FPG}_{\mathrm{T}}(\mathrm{UA})$} & Mean & 54.5 & 83.6 & 57.1 & 53.4 & 4.8 \\
\hline & sd & 41.8 & 42.0 & 44.6 & $\mathrm{p}=0.028^{*}$ & $\mathrm{p}=0.310$ \\
\hline \multirow{2}{*}{$\mathbf{P P G}_{\mathrm{C}}(\mathrm{AU}) / \mathrm{FPG}_{\mathrm{C}}(\mathrm{UA})$} & Mean & 85.8 & 104.4 & 113.8 & 21.6 & 32.6 \\
\hline & sd & 92.2 & 100.5 & 146.3 & $\mathrm{p}=0.028^{*}$ & $\mathrm{p}=0.499$ \\
\hline $\mathbf{P P G}_{\mathrm{T}}$ vs $\mathbf{P P G}_{\mathrm{C}}$ & & $\mathrm{p}=0.535$ & $\mathrm{p}=0.805$ & $\mathrm{p}=0.620$ & - & - \\
\hline \multirow{2}{*}{$\mathbf{P P G}_{\mathrm{E}}(\mathrm{AU}) / \mathrm{FPG}_{\mathrm{E}}(\mathrm{UA})$} & Mean & 16.6 & 17.2 & 15.5 & 3.4 & -6.6 \\
\hline & sd & 8.5 & 8.6 & 7.0 & $\mathrm{p}=0.273$ & $\mathrm{p}=0.273$ \\
\hline \multirow{2}{*}{ SBP (mm Hg) / PAS (mm Hg) } & Mean & 115.3 & 110.1 & 115.4 & -4.6 & 0.04 \\
\hline & sd & 11.0 & 9.3 & 10.3 & $\mathrm{p}=0.018^{*}$ & $\mathrm{p}=0.752$ \\
\hline \multirow{2}{*}{ DBP (mm Hg) / PAD (mm Hg) } & Mean & 71.1 & 64.2 & 68.2 & -9.8 & -4.3 \\
\hline & sd & 5.0 & 3.6 & 4.6 & $\mathrm{p}=0.018^{*}$ & $\mathrm{p}=0.091$ \\
\hline \multirow{2}{*}{ PR (bpm) / FP (bpm) } & Mean & 69.9 & 66.0 & 69.4 & -5.6 & -0.7 \\
\hline & sd & 4.5 & 4.7 & 5.2 & $\mathrm{p}=0.018^{*}$ & $\mathrm{p}=0.128$ \\
\hline \multirow{2}{*}{ RR (bpm) / FR (bpm) } & Mean & 18.9 & 20.5 & 19.0 & 8.2 & 0.2 \\
\hline & sd & 2.0 & 2.8 & 2.3 & $\mathrm{p}=0.018^{*}$ & $\mathrm{p}=0.866$ \\
\hline $\begin{array}{l}\text { Spearman test (LDF vs PPG) / Teste } \\
\text { de Spearman (FLD vs FPG) }\end{array}$ & \multicolumn{6}{|c|}{$\rho=0.673 ; p<0.001^{*}$} \\
\hline
\end{tabular}

\section{Conclusions}

The simultaneous use of these two technologies seems to provide a more sensitive approach to quantify peripheral microcirculation in vivo, allowing the detection of subtle changes in addition to other cardiorespiratory variables, thus expanding the applicability and adding value to this measurement strategy.

\section{Acknowledgements}

The authors would like to express their thanks to all volunteers and to Inês Frazão and Vítor Castelão for their collaboration and assistance.

\section{Conclusões}

O uso simultâneo destas duas tecnologias parece proporcionar uma abordagem mais sensível para quantificar a microcirculação periférica in vivo, permitindo detetar algumas alterações discretas, mas também outras variáveis cardiorrespiratórias, o que expande a sua aplicabilidade e acrescenta um novo valor a esta tecnica de medição.

\section{Agradecimentos}

Os autores desejam expressar os seus agradecimentos a todos os voluntários e à Inês Frazão e Vítor Castelão pela sua colaboração e assistência. 


\section{Conflict of Interests}

The authors declare there are no financial and/or personal relationships that could present a potential conflict of interest.

\section{Conflito de Interesses}

Os autores declaram que não há relações financeiras e / ou pessoais que possam representar um potencial conflito de interesses.

\section{References/ Referências}

1. Pinto PC, Rodrigues LM. An Experimental In Vivo Model to Characterize "Heavy Legs" Symptom in Topical Formulations. Dermatol Res Pract. 2009 doi:10.1155/2009/547039

2. Olin JW, Sealove BA. Peripheral artery disease: current insight into the disease and its diagnosis and management. Mayo Clinic Proceedings 2010 85(7):678-692

3. Menezes JD, Fernandes e Fernandes J, Santos Carvalho C, et al. Estudo da prevalência da doença arterial periférica em Portugal. Angiologia e Cirurgia Vascular. 2009, 5(2):59-68.

4. Holowatz LA, Thompson-Torgerson CS, Kenney WL. The human cutaneous circulation as a model of generalized microvascular function. J App Physiol 2008; 105: 370-372.

5. Silva H, Ferreira H, Bujan MJ, Rodrigues LM. Regarding the quantification of peripheral microcirculation-Comparing responses evoked in the in vivo human lower limb by postural changes, suprasystolic occlusion and oxygen breathing. Microvasc Res. 2015;99:110-7

6. Silva H, Ferreira H, Tavares L, Bujan J, Rodrigues LM. Exploring in vivo models to characterize peripheral microcirculation - a pilot study. Biomed Biopharm Res. 2013; (10)1:65-72

7. Silva H, Ferreira H, Bujan J, Rodrigues LM. Exploring the oxygen challenge test as a microcirculation evaluation model. Biomed Biopharm Res 2013, (10)2:209-215

8. Allen J. Photoplethysmography and its application in clinical physiological measurement. Physiological measurement 2007, 28(3), R1

9. Sahni R. Noninvasive monitoring by photoplethysmography. Clin Perinatol. 2012; 39(3):573-83

10. Sokolnicki LA, Roberts SK, Wilkins BW, Basu A, Charkoudian N. Contribution of nitric oxide to cutaneous microvascular dilation in individuals with type 2 diabetes mellitus. Am J Physiol Endocrinol Metab 2006; 292: E314 -E318

11. Rossi M, Carpi A. Skin microcirculation in peripheral arterial obliterative disease. Biomed Pharmacother 2004;58: 427-431

12. Stewart J, Kohen A, Brouder D, Rahim F, Adler S, Garrick R, Goligorsky MS. Noninvasive interrogation of microvasculature for signs of endothelial dysfunction in patients with chronic renal failure. Am J Physiol 2004; Heart Circ Physiol 287: H2687-E2696

13. Shamim-Uzzaman QA, Pfenninger D, Kehrer C, Chakrabarti A, Kacirotti N, Rubenfire M, Brook R, Rajagopalan S. Altered cutaneous microvascular responses to reactive hyperaemia in coronary artery disease: a comparative study with conduit vessel responses. Clin Sci (Lond) 2002; 103: 267-273

14. Sun Y, Thakor N. Photoplethysmography revisited: from contact to noncontact, from point to imaging. IEEE Transactions on Biomedical Engineering 2016, 63(3):463-477.

15. World Medical Association. World Medical Association Declaration of Helsinki: ethical principles for medical research involving human subjects. JAMA310. 2013, 2191-2194.

16. Rajan V, Varghese B, van Leeuwen TG, Steenbergen W. Review of methodological developments in laser Doppler flowmetry. Lasers Med Sci. 2009, $24: 269-283$.

17. Silva H, Rocha C, Rodrigues LM. Combining laser Doppler flowmetry and photoplethysmography to explore in vivo vascular physiology. Biomed Biopharm Res. 2016; 13(2):209-217

18. Silva H, Rocha C, Brazález BN, Ferreira H, Rodrigues LM. Looking further into photoplethysmography components to study skin circulation. World Congress of the International Society for Biophysics and Imaging of the Skin. Lisbon, Portugal, 31 May-June 32016.

19. Çinar Ș, Eșer I, Khorshıd L. The effects of Back Massage on the Vital Signs and Anxiety Level of Elderly Signs and Anxiety Level of Elderly Staying in a Rest Home, Hacettepe University Faculty of Health Sciences Nursing Journal . 2009; 16(2): 14-21

20. Lee YH, Park BN, Kim SH. The effects of heat and massage application on autonomic nervous system. Yonsei medical journal, 2011; 52(6): 982-989.

21. Moraska A, Pollini RA, Boulanger K, Brooks MZ, Teitlebaum L. Physiological adjustments to stress measures following massage therapy: a review of the literature. Evidence-Based Complementary and Alternative Medicine, 2010 7(4): 409-418.

22. Longworth J. Psychophysiological effects of slow stroke back sponses of individual participants. massage in normotensive females. Adv Nurs Sci 1982 4: 44-61.

23. Weerapong, $\mathrm{P}$ et al. The Mechanisms of Massage and Effects on Performance, Muscle Recovery and Injury Prevention. Sports Med, 2005, 35(3):235256. 